\title{
Actinella species (Bacillariophyta) from an Amazon black water floodplain lake (Amazonas - Brazil)
}

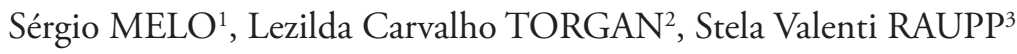 \\ ABSTRACT \\ The genus Actinella Lewis was studied using planktonic samples from a black water floodplain lake in Central Amazon region. \\ For species identification the taxa were morphological and morphometricaly analyzed on base in light microscope (LM) and \\ scanning electronic microscope (SEM). Five species were registered: Actinella brasiliensis Grunow, A. guianensis Grunow, \\ A. gracile Kociolek, A. mirabilis (Eulenstein ex Grunow) Grunow and A. robusta Hustedt. A. gracile is reported for the first \\ time for Amazon State and black water systems and it is firstly documented with SEM. In addition, a review of geographic \\ distribution of Actinella species in Brazilian Amazon region is given.
}

KEYWORDS: Actinella, diatoms; Amazon, black water, floodplain lakes

\section{Espécies de Actinella (Bacillariophyta) de um lago de inundação amazônico de águas pretas (Amazonas - Brasil)}

RESUMO

O gênero Actinella Lewis foi estudado a partir de amostras coletadas em um lago de inundação de águas pretas na Amazônia Central. Para a identificação das espécies as características morfológicas e morfométricas dos táxons foram analisadas em microscopia óptica (MO) e eletrônica de varredura (MEV). Cinco espécies foram identificadas: Actinella brasiliensis Grunow, $A$. guianensis Grunow, A. gracile Kociolek, $A$. mirabilis (Eulenstein ex Grunow) Grunow e $A$. robusta Hustedt. A. gracile é referida pela primeira vez para o estado do Amazonas e para ambientes de águas pretas, sendo documentada pela primeira vez em MEV. Em adição, uma revisão sobre a distribuição geográfica das espécies de Actinella na região da Amazônia brasileira é apresentada.

PALAVRAS-CHAVE: Actinella, diatomáceas, lagos de inundação, águas pretas, Amazônia

1 Instituto Nacional de Pesquisas da Amazônia, E-mail: sergio.melo@pq.cnpq.br

2 Fundação Zoobotânica do Rio Grande do Sul, E-mail: lezilda-torgan@fzb.rs.gov.br

${ }^{3}$ Instituto Nacional de Pesquisas da Amazônia, E-mail: stelaraupp@yahoo.com.br 


\section{INTRODUCTION}

Actinella Lewis 1863 belongs to Eunotiaceae, the only family of raphids diatoms with rimoportulae. Due to both the presence of the rimoportulae and the rudimentar raphe, they constitute an intermediate group between the primitive araphids and the more advanced raphe-bearing (Kociolek, 2000; Kociolek and Spaulding, 2003; Novitski and Kociolek, 2005). This genus presents cells solitary or clustered, the frustules forming star-shaped colonies by the attachment of the smaller ends of the frustules (Patrick and Reimer, 1966). In valve view the valves are slightly curved, expanded at one end (headpole) with short spines on the margins of the valve, attached to solid substrata by the narrow end (footpole).

Actinella species are mainly found, in tropical region (Round et al., 1990) and the main centers of diversity are tropical South America and Africa (Sabbe et al., 2001). Actually, Actinella genus comprises around 60 species, from which around $50 \%$ of them were described in the last ten years: two species from Madagascar, twenty three from South America and six from the Australasian region (Kocioleck et al., 1997; 2001; Metzeltin and Lange Bertalot, 1998; 2002; 2007; Sabbe et al.,2001). In addition A. punctata var. australis Manguin was moved to $A$. australis according to Kociolek et al. (1997) and some Eunotia species were recently transferred to Actinella genus by Metzeltin and Lange Bertalot (2007).

In Amazon State, two Actinella species were described, recently: $A$. disjuncta Metzeltin and Lange-Bertalot and $A$. rionegrenses Metzeltin and Lange-Bertalot, found in Calado lake and Negro River, respectively. In the Negro River basin, ten Actinella species were registered in the literature: $A$. pararobusta Metzeltin et Lange-Bertalot, $A$. pseudohantzschiana Metzeltin and Lange-Bertalot, $A$. brasiliensis; A. curvatula Kociolek, A. gessneri Hustedt, A. guianensis, A. mirabilis, $A$. punctata Lewis, $A$. rionegrenses, $A$. robusta Hustedt, $A$. siolii Hustedt e A. tasmaniensis Hustedt (Uherkovich and Rai, 1979; Uherkovich and Franken, 1980; Furushima and Xavier, 1988; Souza-Mosimann et al., 1997; Putz, 1997; Putz and Junk, 1997; Metzeltin and Lange-Bertalot, 1998; 2007; Díaz-Castro et al., 2003, Melo et al., 2004; 2005, Ferrari et al., 2007).

The aim of this study is to describe Actinella species found in an Amazon black water floodplain lake based on the morphometric and morphologic features in optical and/ or scanning electronic microscope. We also offer information about the geographic distribution of Actinella species in Brazilian Amazon region.

\section{MATERIAL AND METHODS}

This study was based on samples taken in ten stations in Cutiuaú Lake (Table 1), an floodplain lake located on the right bank of Jaú river, an affluent of the right bank of Negro river. These sites are situated in Jaú National Park in the middle Negro river basin. According to Sioli classification (Sioli, 1984), Cutiuaú lake is a typical black water systems, characterized by low $\mathrm{pH}$ and electrical conductivity and high concentrations of humic composts.

A total of 10 samples collected in November 2003 (low water period) were analyzed. The samples were collected by plankton net with mesh size of $25 \mu \mathrm{m}$, and fixed with Transeau solution. An aliquot of sample was concentrated and the frustules were cleaned according to the method of Stoch (1970). For analysis in LM the slides were mounted in Naphrax and examined in a Zeiss Axioplan photomicroscope. For SEM analysis the material was mounted on glass on stubs and metalized with gold-palladium and analized in Jeol JSM -5800 operated at $15-20 \mathrm{kV}$ in the Federal University of Rio Grande do Sul.

The identifications of the taxa were based on Hustedt (1930,1952, 1965), Patrick and Reimer (1966), Krammer and Lange-Bertalot (1991), Metzeltin and Lange-Bertalot (1998, 2002, 2007), Kociolek et al. (2001). Classification system and terminology were based on Round et al. (1990). The analyzed material was stored at the Herbarium (INPA) of the Instituto Nacional de Pesquisas da Amazonia, Manaus, Amazonas, Brazil, numbers 222764-222773 (Table 1).

Table 1 - Sampling stations (SS) with geographic coordinates (GC) and Herbarium number (INPA) of samples collected in Cutiuaú Lake, Jaú National Park, Novo Airão, Amazonas, Brazil on 12/XI/2003

\begin{tabular}{|c|c|c|}
\hline SS & GC & INPA \\
\hline 1 & $01^{\circ} 50^{\prime} 26^{\prime \prime} \mathrm{S} ; 61^{\circ} 37^{\prime} 40^{\prime \prime} \mathrm{W}$ & 222764 \\
\hline 2 & 01050'48'”s; 61037'16"'W & 222765 \\
\hline 3 & 01050'43"'S; 61036'53'”W & 222766 \\
\hline 4 & 01051'11'”S; 61037'17'”W & 222767 \\
\hline 5 & 01051'04'”S; 61036'54'”W & 222768 \\
\hline 6 & 01050'40"'S; 61035'51'”W & 222769 \\
\hline 7 & $01^{\circ} 50^{\prime} 52^{\prime \prime} S ; 61^{\circ} 37^{\prime} 03^{\prime \prime} W$ & 222770 \\
\hline 8 & 01051'38'”; 61037'01'”W & 222771 \\
\hline 9 & 01051'19"'S; 61036'13'”W & 222772 \\
\hline 10 & 01051'01"'S; 61035'54"W & 222773 \\
\hline
\end{tabular}




\section{RESULTS AND DISCUSSION}

\section{TAXONOMICAL CONSIDERATIONS}

Key for Actinella species identification

1. Valves with undulations on both dorsal and ventral margins

A. mirabilis

2. Valves without undulations

3. Headpole and footpole poorly distinct

A. robusta

3. Headpole and footpole clearly distinct from each other 4

4. Footpole cuneate

A. guianensis

4. Footpole rounded

5. Valves narrow, 2.8-4 $\mu \mathrm{m}$ wide

A. gracile

5. Valves broader, usually not less than $4 \mu \mathrm{m}$ wide $A$. brasiliensis

Actinella brasiliensis Grunow in van Heurck, Synopsis des Diatomées de Belgique, Atlas, pl. 35, fig. 19. 1881.

(Figures 1-2)

Valves heteropolar, clavate, weakly arcuate, margins parallel. Headpole broadly spatulate- rounded. Footpole narrowly rounded. Punctate striae, parallel, continue from the valve mantle. Small spines present on the margin of the mantle in SEM view. Length 48-57 $\mu \mathrm{m}$; breadth 4.8-5.5 $\mu \mathrm{m}$; striae 16/ $10 \mu \mathrm{m}$; R 1/b 10-14.

Studied material: INPA 222765, 222767, 222769, 222771, 222772

Actinella gracile Kociolek in Kociolek, Lyon and Spalding, Nova Hedwigia. Studies on Diatoms, p. 131-165. 2001.

(Figures 3-7)

Valves heteropolar, arched, narrow. Ventral margin of the valves concave, dorsal margin convex. Headpole barely swollen. Footpole narrowly rounded. Punctate striae, parallel, continue from the valve mantle, denser and radiate in the headpole. Small spines present on the margin of the mantle and two bigger spines at footpole in SEM view. Length 75-

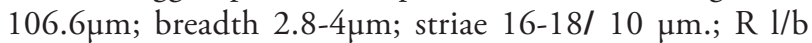
20.8-25.

Studied material: INPA 222770

Actinella guianensis Grunow in van Heurck, Synopsis des Diatomées de Belgique, Atlas, pl. 35, figs. 17, 20. 1881

(Figures 8-10)

Valves heteropolar, moderately arcuate. Headpole spatulate as cuneate. Footpole cuneate, less breadht than headpole. Spines around the valve mantle and footpole with two big spines on the apices visible externally in SEM. view. Punctuate striae, parallel, dense in the poles. Length 112-121.4 $\mu \mathrm{m}$; breadth $6-8.5 \mu \mathrm{m}$ at the center of the valve; striae 7-13/ 10 $\mu \mathrm{m} ; \mathrm{R}$ 1/b 14-18.
Studied material: INPA 222764, 222766, 222769, 222771, 222773

Actinella mirabilis (Eulenstein ex Grunow) Grunow in Van Heurck, Synopsis des Diatomées de Belgique, Atlas, pl. 35: figs. 16 a-c. 1881.

(Figures11-14)

Valves heteropolar, elongate, slightly heteropolar in valve view and arcuate. Apices pointed. Dorsal and ventral margin undulate. Punctuate striae, parallel, dense, continue from the valve face and radiate towards the apices. SEM: Helictoglossa and rimoportula are visible in internally valve view. Spines are present around the valve mantle and one big spine present on the apice of the valve in externally view. Short raphe curves from mantle onto valve face. Length 420-425 $\mu \mathrm{m}$; breadth 16-20 $\mu \mathrm{m}$; striae 9-13/ $10 \mu \mathrm{m}, \mathrm{R}$ 1/b 21-26.

Studied material: INPA 222764, 222765, 222767 , 222768, 222770, 222771, 222773

Actinella robusta Hustedt, Berichte der Deutschen Botanischen Gesellschaft, 65, p.135, pl.5: fig.6. 1952.
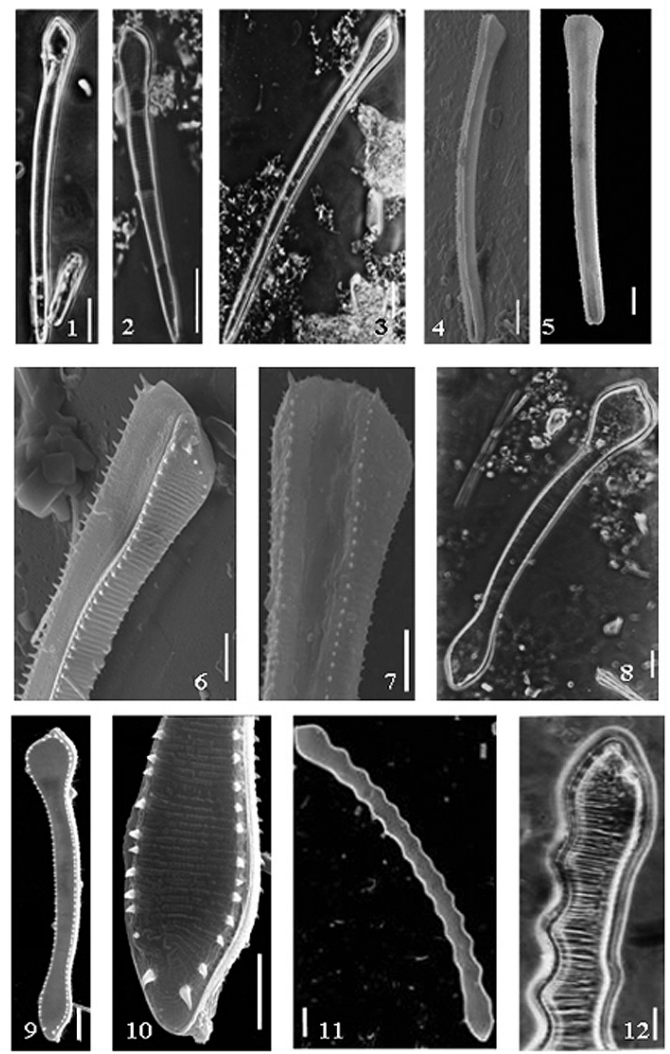

Figures 1-12 - 1, 2. Actinella brasiliensis valve view (LM). 3-7. A. gracile. 3 Valve view (LM). 4. Valve view (SEM). 5. Girdle view (SEM). 6. Detail of the head pole showing the spines (SEM). 7. Head pole with two bigger spines (SEM). 8-10 A. guianensis. 8. General valve view (LM). 9. General valve view (SEM). 10. Detail of the footpole showing the spines. 11,12. A. mirabilis (LM). 11. General valve view. 12. Detail of the foot pole. Scale bars: Figs. 1-4, 8-11 $=10 \mu \mathrm{m}$. Figs $5,12=5 \mu \mathrm{m}$. 
(Figures 15-20)

Valves heteropolar, elongate, slightly arcuate. Apices obtusely rounded, subcapitate in the dorsal margin. Dorsal margin moderately convex. Ventral margin moderately concave. Punctate striae, parallel, continue from the valve face, dense and radiate towards the terminal apices. Length 127.3- $216 \mu \mathrm{m}$; breadth 6.1-7.2 $\mu \mathrm{m}$; breadth in the headpole

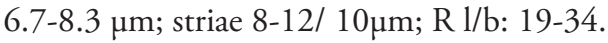

Studied material: INPA 222766, 222768, 222772

\section{GEOGRAPHIC DISTRIBUTION IN BRAZILIAN AMAZON REGION}

There are few published studies that list or describe Actinella species from the Brazilian Amazon region. In addition, they are concentrated in Amazonas and Pará States (Table 2). From 25 registered Actinella species in Brazilian Amazon region, $72 \%$ were described as new species (Table 2). This elevated number of Actinella species in Amazon region has led certain authors to suggest that the Amazon River is a center of diatom diversity (Kociolek et al. 2001).
Actinella is usually found in extremely acid and humic waters, and most of the species are in semitropical or tropical waters (Patrick and Reimer, 1966; Round et al., 1990) with an elevated occurrence in black water systems: environments characterized by low $\mathrm{pH}$ and electrical conductivity and high concentration of humic composts (Sioli, 1984).

This study registers five Actinella species in a black water floodplain lake. A. mirabilis was most frequent, registered in $70 \%$ of analyzed samples, followed by $A$. guianensis and A. brasiliensis. In fact, these species are the most common species in Brazilian Amazon region (Table 2). On the other hand, A. gracile was registered only twice in Pará State and now is documented for first time to Amazon State and black waters systems. In addition it is firstly documented in SEM showing small spines on the margin of the mantle and two bigger spines at footpole.

Table 2 - List of Actinella species found in Brazilian Amazon region. 1= Species found in Amazon State, 2= Species found in Pará State; $3=$ Species found in undefined state. Species in bold type are described based on Brazilian Amazon samples.

\begin{tabular}{|c|c|c|c|c|c|c|c|c|c|c|c|c|c|c|c|}
\hline Species/Authors* & $\mathrm{a}$ & $\mathrm{b}$ & C & $d$ & $\mathrm{e}$ & $f$ & $g$ & $\mathrm{~h}$ & i & j & 1 & $\mathrm{~m}$ & $\mathrm{n}$ & 0 & $p$ \\
\hline A. amazoniana & & & & & & & & & & 2 & & & & & 2 \\
\hline A. brasiliensis & & & 1 & 1 & 1 & 1 & & 1 & 1 & 2 & 1 & 1 & 1 & 1 & \\
\hline A. crawfordii & & & & & & & & & & 2,3 & & & & & 2 \\
\hline A. curvatula & & & & & & & & & & 2 & & & & 1 & 2 \\
\hline A. disjuncta & & & & & & & & & & & & & & & 1 \\
\hline A. eunotioides & 1 & & & & & & & & & 2 & & & & & \\
\hline A. falcifera & & & & & & & & & & & & & & & 2 \\
\hline A. gracile & & & & & & & & & & 2 & & & & & 2 \\
\hline A. gessneri & & 1,2 & & & & & & & & 2 & & & & & 2 \\
\hline A. guianensis & & & & 1 & & & & 1 & 1,2 & 2 & 1 & 1 & 1 & & \\
\hline A. hustedtii & & & & & & & & & & 2 & & & & & 2 \\
\hline A lange-bertalotti & & & & & & & & & & 2 & & & & & \\
\hline A. lima & & & & & & & & & & 3 & & & & & 2 \\
\hline A. kociolekii & & & & & & & & & & & & & & & 3 \\
\hline A. mirabilis & & & 1 & 1 & & & 1 & 1 & 1,2 & 2 & 1 & 1 & 1 & 1 & 1 \\
\hline A. pararobusta & & & & & & & & & 1 & $? 1$ & & & & & 1 \\
\hline A. peroniodes & 1 & & & & & & & & & 2,3 & & & & 1 & 2 \\
\hline A. pseudohanttzschiana & & & & & & & & & 1 & 1,2 & & & & & \\
\hline A. punctata & & & 1 & 1 & & & & & & & & & & & \\
\hline A. rionegrensis & & & & & & & & & & & & & & & 1 \\
\hline A. robusta & 1 & & & 1 & & & & 1 & 3 & 2,3 & 1 & & & 1 & \\
\hline A. siolii & & 1,2 & & & & & & & & 2 & & & & 1 & 2 \\
\hline A. superperonioides & & & & & & & & & & & & & & & 2 \\
\hline A.tasmaniensis & & & & 1 & & & & & & & & & & & \\
\hline A. thelma & & & & & & & & & & & & & & & 2 \\
\hline
\end{tabular}

*Authors: a) Hustedt (1952); b) Hustedt (1965); c) Uherkovich and Rai (1979); d) Uherkovich and Franken (1980); e) Uherkovich (1981); f) Furushima and Xavier (1988); g) Putz (1997) and Putz and Junk (1997); h) Souza-Mosimann et al. (1997); i) Metzeltin and Lage-Bertalot (1998); j) Kociolek et al (2001); I) Diaz-Castro et al. (2003); m) Melo et al. (2004); n) Melo et al. (2005); 0) Ferrari et al. (2007), p) Metzeltin and Lage-Bertalot (2007). 

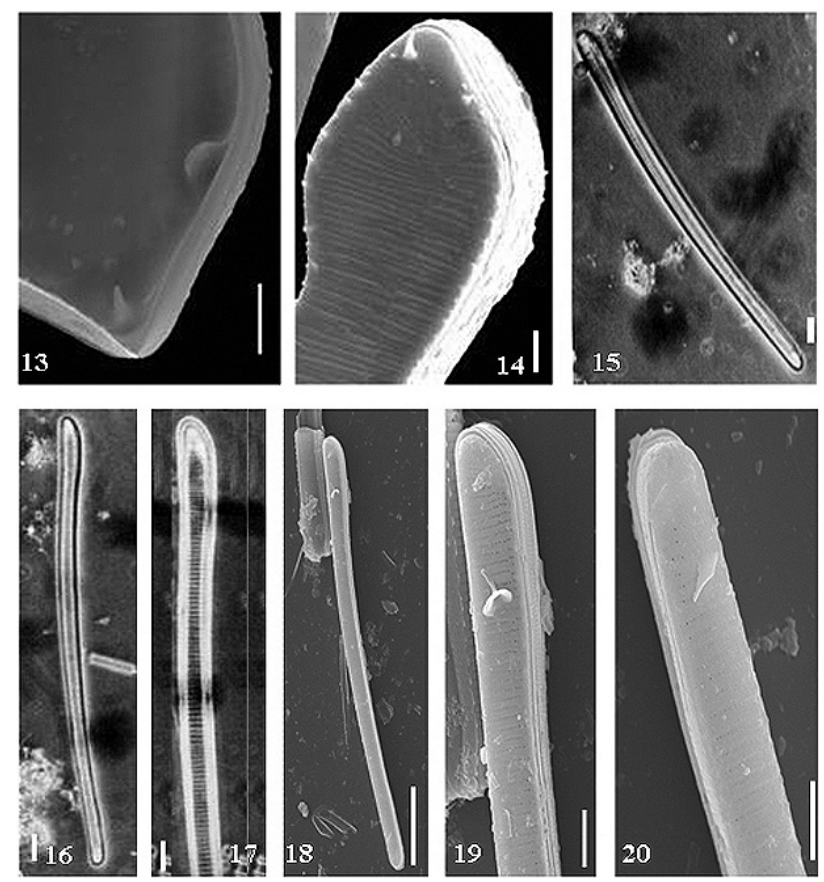

Figures 13-20 - 13, 14. Actinella mirabilis (SEM). 13. Internal view of the headpole showing the helictoglossa and rimoportula. 14. External view of the headpole with a large apical spine. 15-20. A. robusta. 15-17. General valve view (LM). 18. general view (SEM). 19, 20. Detail of the pole showing the raphe on the mantle (SEM). Scale bars: Figs. $14,17=10 \mu \mathrm{m}$. Figs. 13, $15,16,18-19=5 \mu \mathrm{m}$.

\section{ACKNOWLEDGEMENTS}

We would like to acknowledge financial support by CAPES (PRODOC); CNPq (Proc. 473699/2004-4; 302102/2007-8 and fellowships); Fundação Vitória Amazônica; Fundação Zoobotânica do Rio Grande do Sul and MCT-CNPq-INPA for PCI-DTI fellowships.

\section{LITERATURE CITED}

Diaz-Castro, J.J.; Souza-Mosimann, R.M.; Laudares-Silva, R.; Forsberg, B.R. 2003. Composition of the periphytic diatom community of the Jaú river, Amazonas, Brazil. Acta Amazonica, 33 (4): 583- 606 (in Portuguese, with abstract in English).

Ferrari, F.; Procopiak, L.K.; Alencar, Y.B.; Ludwig, T.V.A. 2007. Eunotiaceae (Bacillariophyceae) from central Amazon rivers, Manaus and Presidente Figueiredo districts, Brazil. Acta Amazonica, 37(1): 1-16 (in Portuguese, with abstract in English).

Fukushima, H.; Xavier, M.B. 1988. Attached Diatom from the Negro River, Amazonas, Brasil. Diatom, 4: 11-16.

Hustedt, F. 1952. New and little known diatoms III. Phylogenetic variations in the Rhaphidic Diatoms. Bericchte der Deutschen Botanischen Gesellschaft, 65:133-144 (in German).

Hustedt, F. 1965. New and little known diatoms. IX. Freshwater diatoms from Brazil, especially in the Amazon. Iternationale
Revue der gesamten hydrobiologie und Hydrographie, 50(3):391410 (in German).

Kociolek, J.P. 2000. Valve ultrastructure of some Eunotiaceae (Bacillariophyceae), with comments on the evolution of raphe system. Proceedings of the California Academy of Sciences, 52(2): 11-21.

Kociolek, J.P.; Rhode, K.; Williams, D.M. 1997. Taxonomy, ultrastructure and biogeography of Actinella punctata species complex (Bacillariophyta: Eunotiaceae). Nova Hedwigia, 65:177-193.

Kociolek, J.P.; Lyon, D.; Spaulding, S. 2001. Revision of the South American species of Actinella. In Jahn, R.; Kocioleck, J.P.; Witkowski, A.; Compère, P. (Eds). Studies on diatoms. A.R.G. Gantner Verlag K.G. Koenigstein. p.131-165.

Kociolek, J.P.; Spaulding, S.A. 2003. Eunotioid and Asymmetrical Naviculoid Diatoms. In: Wehr, J. D.; Sheath, R. G. (Eds). Freshwater Algae of North America. Academic Press, London. p. 655-668.

Krammer, K.; Lange-Bertalot, H. 1991. Bacillariophyceae, 3: Centrales, Fragilariaceae, Eunotiaceae. In: Ettl, H.; Gerloff, J.; Heynig, H.; Mollenhauer, D. (Eds). The freshwater flora from Europa Central. G. Fischer . Stuttgart. 576pp (in German).

Melo, S.; Sophia, M. G.; Menezes, M.; Souza, C.A. 2004. Planktonic algae biodiversity of the Jaú National Park: Seringalzinho window. In: Borges, S.H.; Iwanaga, S.; Durigan, C.C.; Pinheiro, M.R. (Eds). Windows for biodiversity in Jaú National Park: A strategy for the study of biodiversity in the Amazon. Manaus, Ed. Ipiranga. Brasília. p.83-94.

Melo, S.; Rebelo, S.R.M.; Souza, K.F.; Menezes, M.; Torgan, L.C. 2005. Phytoplankton. In: Santos-Silva, E N.; Aprile, F.M.; Scudeller, V.V.; Melo, S.(Eds). Biotupé: Environment, biological and sociocultural diversity of the low Negro river, Central Amazon. Ed. INPA. Manaus. p.87-98.

Metzeltin, D.; Lange-Bertalot, H. 1998. Tropical Diatoms of the South America I. Iconographia Diatomologica 5. A.R.G. Gantner Verlag K.G. Koenigstein. 695pp.

Metzeltin, D.; Lange-Bertalot, H. 2002. Diatoms from the "Island Continent” Madagascar. Iconographia Diatomologica 11. A.R.G. Gantner Verlag K.G. Koenigstein.286pp.

Metzeltin, D.; Lange-Bertalot, H. 2007. Tropical Diatoms of the South America II. Iconographia Diatomologica 18: A.R.G. Gantner Verlag K.G. Koenigstein. 877p.

Novitski, L.; Kociolek, P. 2005. Preliminary light and scanning electron microscope observations of narine fossil Eunotia species with comments on the evolution of the genus. Diatom Research, 1: $137-143$.

Patrick, R.; Reimer, C. W. 1966. The diatoms of the United States: exclusive of Alaska and Hawai.1. (Monographs 13). Academy of Natural Sciences. Philadelphia. 688p.

Putz, R. 1997. Periphyton communities in Amazonian black- and whitewater habitats: Community structure, biomass and productivity. Aquatic Sciences, 59: 74-93. 
Putz, R.; Junk, W.J. 1997. Phytoplankton and Periphyton. In:Junk, W.J . (Ed). The central Amazon floodplain: ecology of a pulsing system. Ecological Studies 126. Springer. London. p. 207-222.

Round, F.E.; Crawford, R.M.; Mann, D.G. 1990. The diatoms: Biology and Morphology of the Genera. Cambridge University Press. New York. 747pp.

Sabbe K.; Vanhoutte, K.; Lowe, R.L.; Bergey, E. A.; Biggs, B. J. F.; Francoeur, S.; Hodgson, D.; Vyverman, W. 2001. Six new Actinella (Bacillariophyta) species from Papua New Guinea, Australia and New Zealand: further evidence for widespread diatom endemism in the Australasian region. European Journal of Phycology, 36: 321- 340 .

Sioli, H. 1984. The Amazon and its main affuents: hydrography, morphology of the river course, and river types. In: Sioli, H. (Ed). The Amazon; Limnology and landscape ecology of a mighty tropical river and its basin. Dr. W. Junk Publ. Dordrecht, p.127-165.

Souza-Mosimann, R.M.; Tavares, A.S.; Freitas, V.P. 1997. Contribution of the diatom florule from stomach contents of fish species in Amazonia. I. Myleus sp. (Pacu) of Lago do Prato, AM., Brazil. Acta Amazonica, 27 (1): 9-26 (in Portuguese, with abstract in English).
Stosch, H. A. von. 1970. Methods for preparation of small or delicate siliceous elements for the electron and light microscopy, especially of diatoms and small quantities of material. Zeitschrift für wissenschaftlichen Mikroscopie, 70: 29-32 (in German).

Uherkovich, G. 1981. Algae from some Amazonian waters. Amazoniana, 7(2): 191-219. (in German with abstract in Portuguese).

Uherkovich, G.; Rai, H. 1979. Algae from the Rio Negro and its affluents. Amazoniana, 6(4): 611-638. (in German with abstract in Portuguese).

Uherkovich, G.; Franken, M. 1980. Periphytic algae from central Amazonian rain forest streams. Amazoniana, 7 (1): 49-79. (in German with abstract in Portuguese)

Recebido em 21/08/2008

Aceito em 15/12/2009 